Collins takes over an NIH awash with cash, yet bracing for leaner times after a one-time bolus of US $\$ 10.4$ billion in economic stimulus spending runs out in September 2010. Spending the money both rationally and quickly is already proving a daunting challenge for the $\mathrm{NIH}$ - the world's largest funder of biomedical research - whose peer-review system is close to being overwhelmed by a flood of applications (see Nature 459, 763; 2009). "Everybody and their brother is going to have an idea of how to do this," says Tilghman. "He's going to have to sift through all those ideas and plans and ultimately do what is best for the United States. And he is going to have to do it relatively quickly."

Since Obama's 2010 budget requested only a $1.4 \%$ increase for the \$30.3-billion agency, the NIH could also face the kind of boom and bust it confronted in 2003, when its rapidly expanded ranks of scientists were left competing for slices of a suddenly very finite pie. "He's going to have to fight for budget," says Paul Nurse, the Nobelprizewinning biologist who is president of the Rockefeller University in New York.

The NIH is a behemoth that now has 27 institutes and centres and about 18,000 employees - much larger than the more focused NHGRI. "A big challenge for him is going to be to shift into a new role from his old role," says Elias Zerhouni, who left the NIH director's job last October. "You can't just dictate what you think is right. You have to listen a lot more."

White House rules prevent Collins from speaking to journalists before his nomination is considered by the Senate Committee on Health, Education, Labor, and Pensions, chaired by Senator Edward Kennedy (Democrat, Massachusetts). Kennedy has called the choice of Collins "inspired", and said he would work to see that the nomination is approved "without delay". Meredith Wadman

and fax requests for information, says Andrea Bosman, an official at the WHO's Global Malaria Programme (see http://tinyurl.com/m4gqmn).

Regulatory authorities in just 39 of the 76 countries using malaria drugs have so far complied or said they intend to comply with the WHO's recommendations (see http://tinyurl.com/ m94wqk). National regulatory authorities could help by banning monotherapies, says Bosman, but many are weak, understaffed and lack expertise.

"It's terrible," says Bosman, adding that every country where malaria is endemic is affected by the problem. "Who says there is no profit to be made in malaria? When you see the number of companies operating in Africa, and the diversity of products, you'd just be amazed."

Declan Butler

\title{
Flu furore hits Argentina
}

\section{BUENOS AIRES}

Argentina's government has for more than two weeks ignored recommendations from a committee of influenza experts to declare a national health emergency. Such a declaration would prompt greater federal resources to combat the spread of the pandemic H1N1 2009 virus.

The committee, specifically set up to advise the Ministry of Health on swine flu, issued its call just days before Argentina's national election on 28 June, which it feared could accelerate the spread of the virus.

Following the committee's call for action, the health minister, Graciela Ocaña, asked for the election to be postponed, but her request was rejected. Ocaña subsequently resigned and left office on 29 June. Mirta Roses, director of the Pan American Health Organization - the Latin American and Caribbean arm of the World Health Organization (WHO) - has also criticized the decision to go ahead with the elections.

"The delay was recommended because the agglomeration of people in places with little ventilation favours the transmission of the disease," says Jorge San Juan, coordinator of the expert committee and head of the intensive-care unit at Muñiz Hospital in Buenos Aires. The government now faces two lawsuits brought by individual lawyers who claim that its decision not to delay the elections recklessly endangered its citizens, who are legally required to vote.

Epidemiologist Emilio Santabaya, former head of the Malbrán Institute in Buenos Aires - the country's main flu monitoring centre - adds that Argentina knew an epidemic was coming and did nothing, and that flu monitoring in the country is not adequate to track the spread of the virus. The situation contrasts with that of neighbouring country Chile, which has many more flu surveillance centres, according to Jorge Jimenez, who has worked both as Chile's health minister and as chairman of the WHO's executive committee. On 7 July, Chilean President Michelle Bachelet, who trained as an epidemiologist, signed a decree that gives health authorities in the country the power to cancel events that could spread swine flu.

Meanwhile, a group of doctors, hospital workers and scientists called Médicos Sin Banderas (Doctors without Flags) has also accused the national government of deliberately hiding the full extent of the swine-flu outbreak.

Ariel Umpierrez, a health economist who heads the group, says that its members have been sharing information about flu cases from their places of work across the country. Those data show that the government has lowered the official number of cases by excluding infected people who visit private clinics, he argues. Argentina's Ministry of Health has not

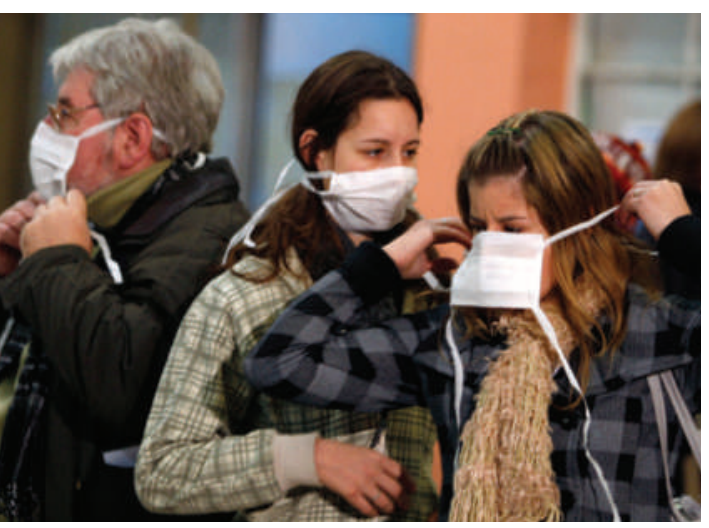

Argentines have been travelling abroad to buy flu drugs. responded to Nature's queries on the matter.

Although scientists inside the country say they are being ignored, those outside are worried by reports of panicked Argentines travelling to Chile and Uruguay to buy flu drugs. The drugs, which are being taken without medical advice, are probably being used in a way that promotes the development of resistance, says Eric Toner, a senior associate at the University of Pittsburgh's Center for Biosecurity in Pennsylvania. Because Uruguay is heavily dependent on trade with Argentina, it is highly unlikely to prevent Argentines from entering the country - but the governments of Brazil and Bolivia are considering closing their borders to prevent the spread of infection. Anna Petherick 